A

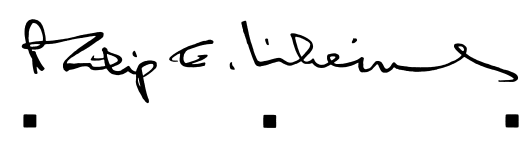

$\mathrm{B}$ O O K

The Philip E. Lilienthal imprint

honors special books

in commemoration of a man whose work

at University of California Press from 1954 to 1979

was marked by dedication to young authors

and to high standards in the field of Asian Studies.

Friends, family, authors, and foundations have together

endowed the Lilienthal Fund, which enables UC Press

to publish under this imprint selected books

in a way that reflects the taste and judgment

of a great and beloved editor. 
The costs of publishing this book have been defrayed in part by the Hiromi Arisawa Memorial Awards from the Books on Japan Fund. The awards are financed by The Japan Foundation from generous donations contributed by Japanese individuals and companies. 
MILLENNIAL MONSTERS 
ASIA: LOCAL STUDIES/GLOBAL THEMES

Jeffrey N. Wasserstrom, Kären Wigen, and Hue-Tam Ho Tai, Editors

1. Bicycle Citizens: The Political World of the Japanese Housewife, by Robin M. LeBlanc

2. The Nanjing Massacre in History and Historiography, edited by Joshua A. Fogel

3. The Country of Memory: Remaking the Past in Late Socialist Vietnam, by Hue-Tam Ho Tai

4. Chinese Femininities/Chinese Masculinities: A Reader, edited by Susan Brownell and Jeffrey N. Wasserstrom

5. Chinese Visions of Family and State, 1915-1953, by Susan L. Glosser

6. An Artistic Exile: A Life of Feng Zikai (1898-1975), by Geremie R. Barmé

7. Mapping Early Modern Japan: Space, Place, and Culture in the Tokugawa Period, 1603-1868, by Marcia Yonemoto

8. Republican Beijing: The City and Its Histories, by Madeleine Yue Dong

9. Hygienic Modernity: Meanings of Health and Disease in Treaty-Port China, by Ruth Rogaski

10. Marrow of the Nation: A History of Sport and Physical Culture in Republican China, by Andrew D. Morris

11. Vicarious Language: Gender and Linguistic Modernity in Japan, by Miyako Inoue

12. Japan in Print: Information and Nation in the Early Modern Period, by Mary Elizabeth Berry

13. Millennial Monsters: Japanese Toys and the Global Imagination, by Anne Allison

14. After the Massacre: Commemoration and Consolation in Ha My and My Lai, by Heonik Kwon 


\section{Millennial Monsters}

Japanese Toys and the Global Imagination

\section{ANNE ALLISON}

Foreword by GARY CROSS

甲

UNIVERSITY OF CALIFORNIA PRESS

Berkeley Los Angeles London 
University of California Press, one of the most distinguished university presses in the United States, enriches lives around the world by advancing scholarship in the humanities, social sciences, and natural sciences. Its activities are supported by the UC Press Foundation and by philanthropic contributions from individuals and institutions. For more information, visit www.ucpress.edu.

University of California Press Berkeley and Los Angeles, California

University of California Press, Ltd.

London, England

(C) 2006 by The Regents of the University of California

Library of Congress Cataloging-in-Publication Data

Allison, Anne, 1950-

Millennial monsters : Japanese toys and the global imagination / Anne Allison ; foreword by Gary Cross.

p. cm.-(Asia-local studies/global themes; 13)

Includes bibliographical references and index.

ISBN 0-520-22148-6 (cloth : alk. paper)—ISBN 0-520-24565-2 (pbk. : alk. paper)

1. Toys_Japan. 2. Games-Japan. 3. Animated films-Japan. 4. Video games-Japan. 5. Consumer goods-Japan. 6. Toy industryJapan. 7. Toys-Japan-Marketing. 8. Philosophy, Japanese. 9. JapanSocial life and customs. I. Title. II. Series.

GN635.J2A55 2006

$688.7^{\prime} 20952-\mathrm{dc} 22$

2005025770

Manufactured in the United States of America

$\begin{array}{llllllllll}15 & 14 & 13 & 12 & 11 & 10 & 09 & 08 & 07 & 06\end{array}$

$\begin{array}{llllllllll}10 & 9 & 8 & 7 & 6 & 5 & 4 & 3 & 2 & 1\end{array}$

The paper used in this publication meets the minimum requirements of ANSI/NISO Z39.48-1992 (R 1997) (Permanence of Paper). 
To Charlie 
